\title{
Blubber fatty acid profiles reveal regional, seasonal, age-class and sex differences in the diet of young Steller sea lions in Alaska
}

\author{
Carrie A. Beck ${ }^{1,2,{ }^{*}}$, Lorrie D. Rea ${ }^{1}$, Sara J. Iverson ${ }^{3}$, John M. Kennish ${ }^{2}$, \\ Kenneth W. Pitcher ${ }^{1}$, Brian S. Fadely ${ }^{4}$ \\ ${ }^{1}$ Alaska Department of Fish \& Game, Division of Wildlife Conservation/Marine Mammals, 525 W. 67th Avenue, Anchorage, \\ Alaska 99518, USA \\ ${ }^{2}$ University of Alaska Anchorage, Department of Chemistry, 3211 Providence Drive, Anchorage, Alaska 99508, USA \\ ${ }^{3}$ Dalhousie University, Department of Biology, Halifax, Nova Scotia B3H 4J1, Canada \\ ${ }^{4}$ National Marine Mammal Laboratory, NOAA Fisheries, Alaska Fisheries Science Center, 7600 Sand Point Way NE, Seattle, \\ Washington 98115, USA
}

\begin{abstract}
Blubber fatty acid (FA) profiles of young Steller sea lions Eumetopias jubatus $(<24$ mo old; $\mathrm{n}=477$ ) were investigated to determine whether regional, seasonal, age-class and sex differences occur in the diets of these demographic groups. Blubber FA profiles of spring (March to May) pups differed significantly by region, probably reflecting regional differences in the diet of adult females, who provide their pups with milk. While there were statistically significant seasonal and age-class differences in both Prince William Sound (PWS) and SE Alaska (SEA), differences in FA profiles between sexes were only evident in the blubber of yearlings from PWS. Within SEA, blubber FA profiles of summer pups differed significantly from all other seasonal/age-class groups in that region. This is consistent with movements of female-pup pairs from rookeries to haul-outs and hence differences in female foraging. In SEA, seasonal differences in blubber FA composition were evident and similar between yearlings and pups. In contrast, there was a gradual change in the FA profile of pup blubber from summer to spring in PWS, which did not follow the same seasonal pattern of yearling profiles. These differences in FA profiles suggest either differences in the timing of weaning between the 2 areas or shifts in the diets of lactating females, or both.
\end{abstract}

KEY WORDS: Fatty acids · Dietary intake $\cdot$ Eumetopias jubatus $\cdot$ Independent foraging

\section{INTRODUCTION}

The transition to nutritional independence and subsequent juvenile survival is an important component of the population dynamics in many mammalian species (Blumstein \& Foggin 1997, Beauplet et al. 2005). In pinnipeds, declines in population size of Hawaiian monk seals Monachus schauinslandi and Steller sea lions (SSL) Eumetopias jubatus have been theoretically (York 1994) and empirically (Craig \& Ragen 1999, Pendleton et al. 2006) attributed to reduced juvenile survival. In the endangered western stock of SSL, the causes of reduced juvenile survival are uncertain. Nevertheless, a change in quality and/or quantity of preferred prey species has been one of the leading hypotheses to explain reduced survival (Merrick et al. 1997, Trites \& Donnelly 2003). Juveniles, specifically newly weaned individuals, may be particularly vulnerable to changes in prey quality or quantity given their limited foraging experience and range (Merrick \& Loughlin 1997, Craig \& Ragen 1999).

The western stock (west of $144^{\circ} \mathrm{W}$; Prince William Sound to Russia) of SSLs declined by up to $85 \%$ between 1970 and 2000 (Merrick et al. 1987, Sease et 
al. 2001), leading to the listing status 'endangered' under the US Endangered Species Act. In contrast, the genetically distinct (Bickham et al. 1996) eastern SSL stock (east of $144^{\circ} \mathrm{W}$; SE Alaska, to California) increased by $150 \%$ over the same time period (Calkins et al. 1999, Sease et al. 2001). The different population trends evident in the western and eastern stocks has led researchers to compare various aspects of SSL ecology (e.g. Brandon et al. 2005) and physiology (e.g. Zenteno-Savin et al. 1997) to elucidate the mechanism(s) that generated population decline in the west. To further investigate differences between the 2 stocks it is useful to gain a better understanding of juvenile foraging behavior and diet (Raum-Suryan et al. 2004).

Recent estimations of SSL diets have been based on the analysis of fecal samples collected at haul-outs and rookeries (e.g. Merrick et al. 1997, Sinclair \& Zeppelin 2002). Although these studies have been informative, the diet of specific age groups cannot be determined as scats cannot be linked with individual SSLs. Given the known dietary and foraging differences between adults and juveniles in a variety of vertebrate species (e.g. harbor seals Phoca vitulina [see review by HooverMiller 1988], hoary bats Lasiurus cinereus [Rolseth et al. 1994] and birds [Marchetti \& Price 1989]), it is critical to use a method which can match sample data to individuals. Using digestion-resistant hard parts found in the stomachs of adult and juvenile ( $\leq 4 \mathrm{yr}$ old) SSLs, Merrick \& Calkins (1996) found that juveniles around Kodiak Island (KOD) consumed small forage fish more frequently, and flatfish and cephalopods less frequently, than adults from the same area, suggesting that age differences in diet exist for this species. Nevertheless, the use of digestion-resistant prey hard parts collected from stomachs or scats can bias our understanding of diet (Jobling \& Breiby 1986, Pierce \& Boyle 1991, Bowen 2000). For example, if diagnostic hard parts are not consumed by the predator (e.g. crustacean shells) these prey items will not be identified in the diet. Additionally, differential rates of digestion of hard parts (Bowen 2000) may bias diet estimates in favor of prey species with large robust hard parts.

These difficulties and biases have lead to the development of alternative methods to understand foraging patterns and diet differences, including analysis of fatty acid (FA) profiles. Marine ecosystems contain a diverse array of FAs (Ackman 1980), which are consumed and deposited in a predator's adipose tissues with little or no modification (Ackman \& Eaton 1966, Cook 1991) or in a predictable way (Lhuillery et al. 1988, Summers et al. 2000, Cooper 2004, Iverson et al. 2004). Predator FA profiles are also influenced by the biosynthesis of certain FAs and the reduced deposition of others. As a result, the predator's FA profile will never exactly match that of their prey. Nevertheless, the FA profile of a predator's adipose tissue has been shown to reflect the FA profile of consumed prey in many marine taxa (e.g. Holland et al. 1990, Raclot et al. 1998, Herman et al. 2005). One of the advantages of FA analysis is that, due to the manner in which FAs are deposited in adipose tissue, FA profiles represent an integration of the predator's diet over several weeks to months and represents all species eaten, rather than the most recently consumed prey. In addition, because tissue samples can be collected directly from individuals, relationships between phenotypic and demographic characteristics of the animal can be tested.

The FA profile of a predator can be used to investigate diet in 2 ways. Quantitative estimation of the predator's diet is possible using the FA profile of the predator and that of its prey (Iverson et al. 2004). However, adequate data on the FA composition of all potential prey species and an understanding of how a predator metabolizes individual FAs (i.e. calibration coefficients, see Iverson et al. 2004) are required. In the absence of prey FA and calibration data, FA profiles of predators are useful to detect qualitative dietary changes and differences among demographic groups (e.g. Walton et al. 2000, Beck et al. 2005, Herman et al. 2005), based on the established understanding that FA structures are transferred across trophic levels largely unchanged (e.g. Ackman \& Eaton 1966, Cook 1991). Despite some debate in recent years over the use of this method of dietary investigation in apex predators (Grahl-Nielsen et al. 2003, 2004, Thiemann et al. 2004), the qualitative use of FA has proven to be useful in elucidating geographical (e.g. Walton et al. 2000), ecotype (e.g. Herman et al. 2005) and sex (e.g. Beck et al. 2005) differences in diet, among a broad range of taxa, when appropriate sampling and chemical analysis of the predator's tissue is conducted (Thiemann et al. 2004).

In this study, we qualitatively investigated the blubber FA profiles of young SSLs ( $<24$ mo old) and tested for regional, seasonal, age-class and sex differences in FA profiles. We hypothesized that the FA profile, and thus diet, of young SSLs would differ by region and season given the known temporal and spatial variation in prey assemblages throughout their Alaskan range. We also predicted that the FA profile of young SSLs would differ by age-class as individuals transition from maternal dependence on milk to independent foraging on prey. SSLs exhibit a long and variable period of lactation (Calkins \& Pitcher 1982, Merrick \& Loughlin 1997) and it has proven difficult to determine when the transition to independent foraging occurs in this species. Some SSL offspring are thought to wean at the end of their first year (11 to 12 mo old) just prior to the female giving birth to the next year's pup (Loughlin et al. 2003), although precise dates have not been determined. However, there is evidence of maternal depen- 
dence continuing, in some cases, until offspring are 2 or $3 \mathrm{yr}$ of age (Pitcher \& Calkins 1981, Pitcher et al. 2004). By investigating the variation in FA profile by age and sex we further explored this diet transition at weaning in young SSLs.

\section{MATERIALS AND METHODS}

Sample collection. Between March 1998 and February 2004, blubber samples were collected from 477 individual SSLs (Table 1), ranging in age from 0.5 to $23.5 \mathrm{mo}$, in 3 regions of the western stock (PWS, KOD, and the Aleutian Islands, AI) and 1 region in the eastern stock (SEA $;$ Fig. 1). Ages were estimated based on canine length, patterns of tooth eruption (King et al.
2007; a technique verified by a sample of 47 knownage individuals between the ages of 2 and $44 \mathrm{mo}$ ) and standard length (Alaska Department of Fish \& Game unpubl. data) assuming a mean calendar birth date of June 15 for all individuals.

Individuals were captured underwater near haulouts or rookeries (Raum-Suryan et al. 2004) or on land with hoop nets. Captured sea lions were transported to a research vessel, weighed to the nearest $0.1 \mathrm{~kg}$ and immobilized with isoflurane gas anesthesia (Heath et al. 1997). During anesthesia, a $3 \mathrm{~cm}^{2}$ area on the dorsal right flank of the sea lion was shaved and washed with povidone-iodine (Betadine solution) and alcohol before making a $1 \mathrm{~cm}$ incision through the epidermis with a sterile scalpel blade. A full-depth blubber biopsy was collected from this site using a sterile $6 \mathrm{~mm}$ biopsy

Table 1. Eumetopias jubatus. Number of Steller sea lion blubber samples collected between March 1998 and February 2004 by region, season, year and age-class. P, Y: pups and yearlings, respectively; SEA: SE Alaska; PWS: Prince William Sound; KOD: Kodiak Island; AI: Aleutian Islands

\begin{tabular}{|c|c|c|c|c|c|c|c|c|c|c|c|}
\hline \multirow{2}{*}{ Year } & \multicolumn{4}{|c|}{ - SEA } & \multicolumn{3}{|c|}{ - PWS -} & \multicolumn{2}{|c|}{$-\mathrm{KOD}-$} & \multicolumn{2}{|c|}{$-\mathrm{AI}$} \\
\hline & Summer & Fall & Winter & Spring & Summer & Fall & Spring & Summer & Spring & Fall & Spring \\
\hline 1998 & & & & $10 \mathrm{P} / 8 \mathrm{Y}$ & & & & & & & \\
\hline 1999 & $12 \mathrm{P}$ & & & & & & & & & & \\
\hline 2000 & & $13 \mathrm{P} / 17 \mathrm{Y}$ & $10 \mathrm{P} / 4 \mathrm{Y}$ & & $13 \mathrm{P} / 14 \mathrm{Y}$ & & $11 \mathrm{P} / 5 \mathrm{Y}$ & & & & \\
\hline 2001 & $10 \mathrm{P} / 23 \mathrm{Y}$ & & & $28 \mathrm{P}$ & & 21P/10Y & & & $13 \mathrm{P}$ & $17 \mathrm{P} / 1 \mathrm{Y}$ & \\
\hline 2002 & $18 \mathrm{Y}$ & $11 \mathrm{P} / 12 \mathrm{Y}$ & & & & $6 \mathrm{P} / 9 \mathrm{Y}$ & $20 \mathrm{P} / 9 \mathrm{Y}$ & $7 Y$ & $15 \mathrm{P}$ & & $25 \mathrm{P}$ \\
\hline 2003 & $15 \mathrm{P}$ & $8 \mathrm{P} / 9 \mathrm{Y}$ & & & & $18 \mathrm{P} / 12 \mathrm{Y}$ & & & $6 \mathrm{P}$ & & $11 \mathrm{P} / 4 \mathrm{Y}$ \\
\hline 2004 & & & $20 \mathrm{P} / 5 \mathrm{Y}$ & & & & & & & & \\
\hline Total & $37 \mathrm{P} / 41 \mathrm{Y}$ & $32 \mathrm{P} / 38 \mathrm{Y}$ & $30 \mathrm{P} / 9 \mathrm{Y}$ & 38P/8Y & $13 \mathrm{P} / 14 \mathrm{Y}$ & $45 \mathrm{P} / 31 \mathrm{Y}$ & $31 \mathrm{P} / 14 \mathrm{Y}$ & $7 Y$ & $33 P$ & $17 \mathrm{P} / 1 \mathrm{Y}$ & $34 \mathrm{P} / 4 \mathrm{Y}$ \\
\hline
\end{tabular}

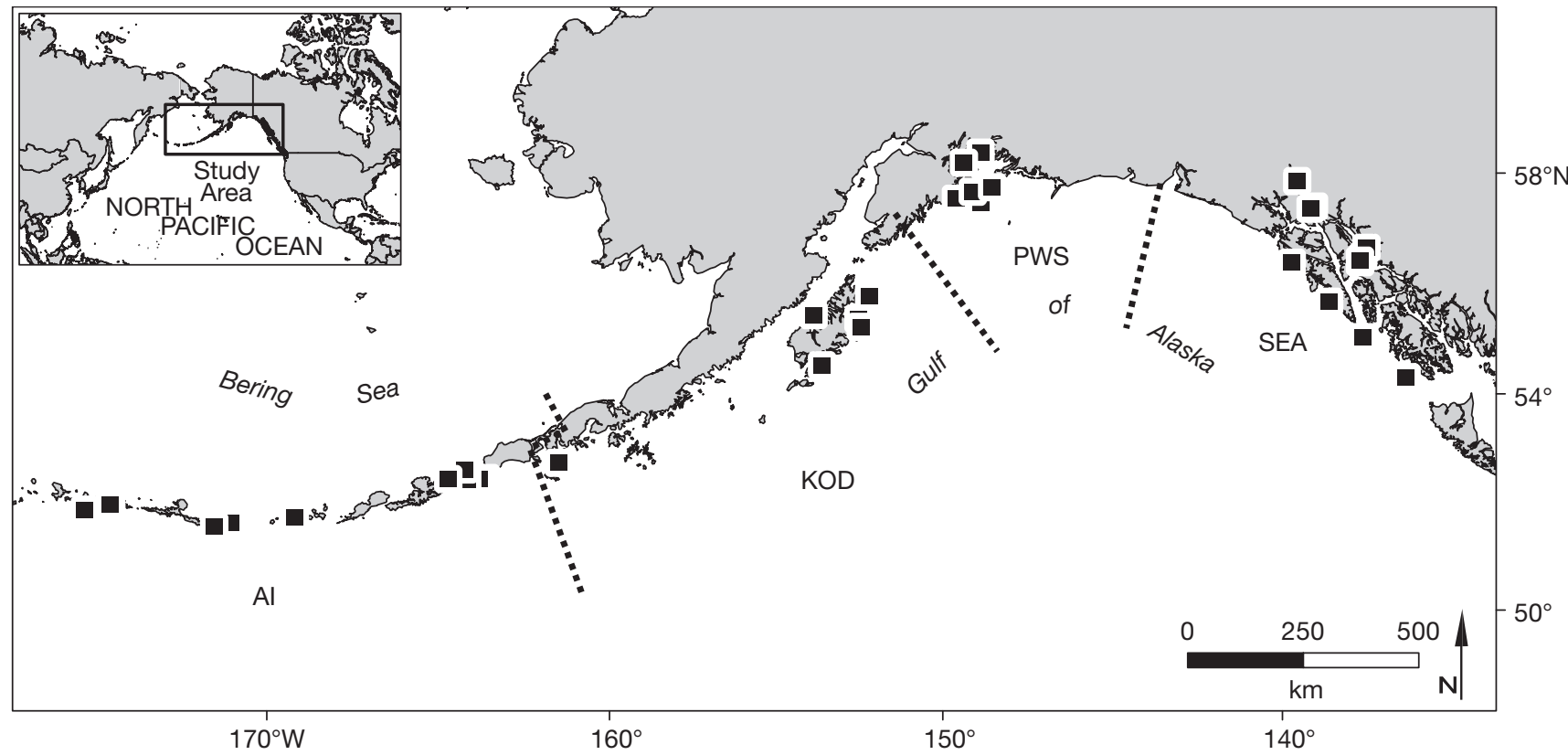

Fig. 1. Eumetopias jubatus. Alaska Steller sea lion range. (ם) Sampling locations in this study. Regions delineated by dotted lines based on Merrick et al. (1987). SEA: SE Alaska; PWS: Prince William Sound; KOD: Kodiak Island; AI: Aleutian Islands 
punch. The incision was not sutured and subsequent recapture of 12 of these individuals showed good healing at this site. Blubber samples were wrapped in acetone-washed aluminum foil, placed in a polyethylene sample bag (Whirl-Pak ${ }^{\odot}$ ), and stored on dry ice while in the field. Once in the laboratory, samples were placed in a solution of 2:1 chloroform/methanol containing $0.01 \% 2,6$,-di-tert-butyl-4-methyl-phenol $(\mathrm{BHT})$ and stored frozen $\left(-80^{\circ} \mathrm{C}\right)$ until processed.

We chose to collect and analyze the full-depth blubber core in this study on young SSLs. Although previous studies have indicated that the blubber of cetaceans can be highly stratified (e.g. Koopman 2001), stratification of individual FAs, while present, is far less in pinniped species. Recent studies have shown that, in pinnipeds, the FAs in the inner portion of the blubber layer (i.e. closest to the muscle) turn over more quickly than the outer layer, such that the inner-half of the blubber layer may reflect recent (i.e. within the previous 2 wk) dietary FAs intake (Cooper 2004). However, whole, full-depth blubber cores, avoiding the nearskin FAs, provide the long-term (months) integration of dietary FAs (e.g. Cooper 2004, Iverson et al. 2004). Thus, our interest in the long-term integration of the diet in young SSLs was most appropriately addressed by analyzing the full-depth blubber core.

Laboratory procedures. Lipid was extracted from each full-depth blubber sample using a modified Folch method (Folch et al. 1957, Iverson et al. 2001). FA methyl esters (FAME) were prepared as described in Iverson et al. (1997). FAME from samples collected prior to 2000 were analyzed at Dalhousie University in Halifax, Nova Scotia as described in Budge et al. (2002). After 2000, FAME were analyzed at the Applied Science, Engineering and Technology laboratory at the University of Alaska Anchorage as described in Dodds et al. (2004). In both laboratories, specific FAs were identified using known standard mixtures (Sigma, Supelco, Matreya and/or Nu-check Prep), silver nitrate (argentation) chromatography, and gas chromatography/mass spectrometry. Individual FAs are reported as percent weight of total FAs and are designated using the shorthand nomenclature of carbon chain length: number of double bonds and location $(\mathrm{n}-\mathrm{x})$ of the double bond nearest the terminal methyl group.

A set of 12 SSL FAME samples were analyzed in both laboratories to assure compatibility of analyzed samples. There was no significant statistical difference between the 2 laboratories in the resulting FA composition of samples when compared using univariate $t$-tests with a Bonferroni correction factor for multiple comparisons. This analysis was conducted using all 66 FAs identified by both laboratories (statistically significant $p$ $=0.0007 ; \mathrm{p}$-value range 0.9100 to 0.0009 ) and for the subset of 20 FAs (see below) used in the analysis (statistically significant $\mathrm{p}=0.0025$; $\mathrm{p}$-value range 0.9280 to 0.0027 ). The average percent difference between labo-

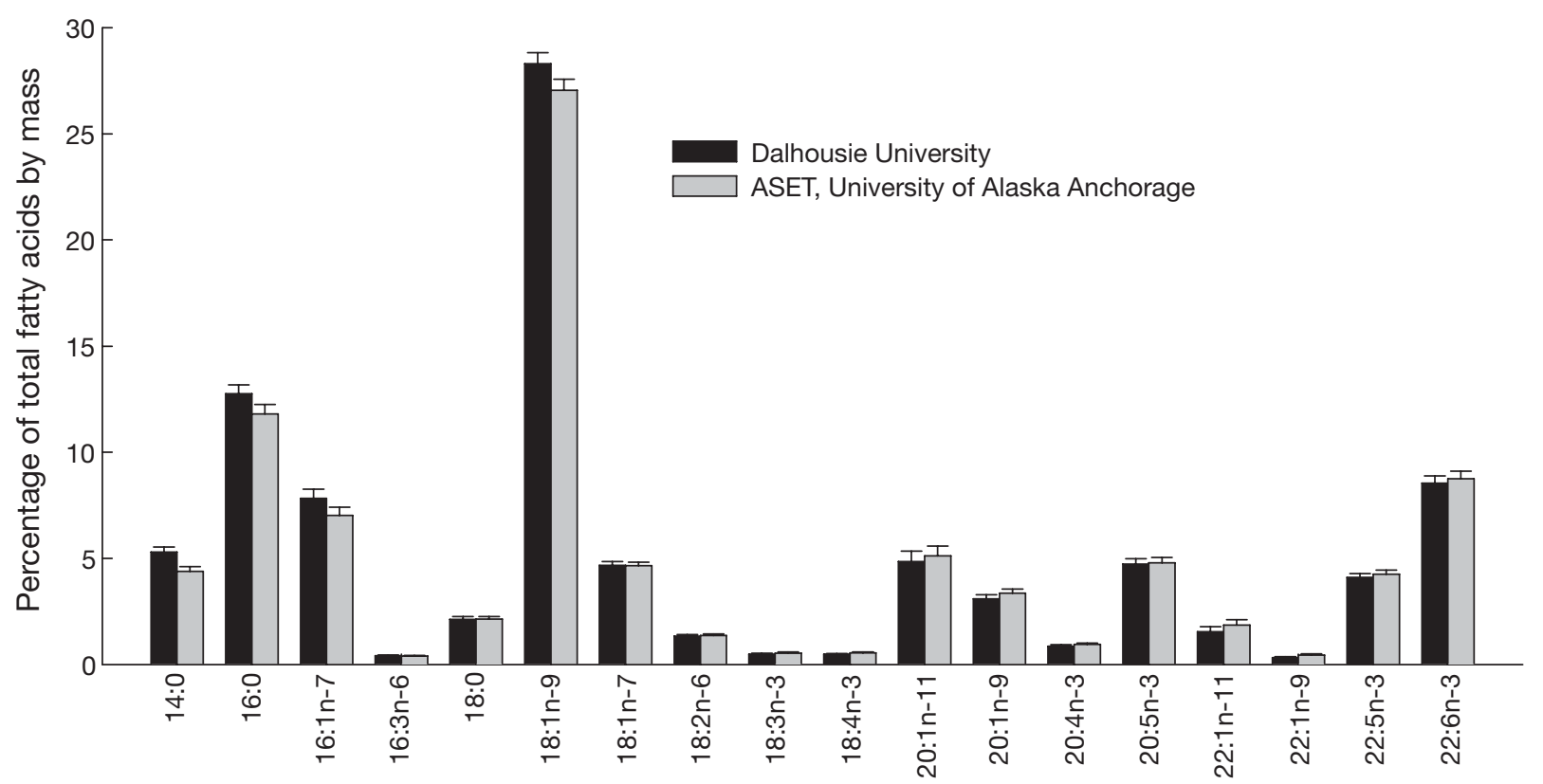

Fig. 2. Eumetopias jubatus. Mean $(+1 \mathrm{SE})$ select abundant fatty acids quantified in blubber samples of 12 young $(<24 \mathrm{mo})$ Steller sea lions analyzed at Dalhousie University in Halifax, Nova Scotia and in the Applied Science, Engineering, and Technology (ASET) laboratory at the University of Alaska Anchorage. There were no significant differences in FA profile composition between laboratories (univariate $t$-tests with Bonferroni correction factor [statistically significant $\mathrm{p}=0.001$ ]; all $\mathrm{p}$-values $<0.001$ ) 
ratories for individual FAs ranged from 0 to $1.24 \%$ (Fig. 2).

Statistical analysis of fatty acid profiles. General linear models (MANOVA) and discriminant function analysis (DFA) were used to examine regional, seasonal, age-class and sex differences in the FA profiles (and thus diet) of young SSLs. Samples collected between June 1 and August 31 were considered to be summer samples, while those collected between September 1 and November 30, December 1 and February 28, and March 1 and May 31, were considered to be fall, winter and spring samples, respectively. Individuals $<12$ mo old were classified as pups whereas those between 12 and 24 mo were considered yearlings. Because of the uneven yearly sampling of SSLs by regions and seasons (Table 1), samples were pooled among years for statistical analysis of regional and seasonal variability. Although inter-annual shifts in diet have been observed in a variety of pinniped species (Merrick et al. 1997, Beck et al. 2005), the sampling logistics of this study prevented an inter-annual analysis of this data.

MANOVA and DFA require that the number of samples in each group exceed the number of variables used in the analysis to avoid over-fitting of the data and to provide reasonable assurance that the covariance matrices are homogeneous (Stevens 1986). Thus, although 66 individual FAs were routinely identified and quantified, only a subset ( $\mathrm{n} \leq 20$; Table 2 ) of FAs were used to examine the variability in SSL profiles due to limited and uneven sampling across regions, seasons and/or age-classes. The subsets of FAs used in each analysis were the most variable and abundant of the FAs that are dominantly or solely derived from dietary intake (see Iverson et al. 2004, their Appendix A).

Two separate analyses were conducted. The first examined regional and sex-related variation and included only blubber data collected from spring pups to control for age and seasonal effects while still providing the largest sample size across regions (Table 1). The second set of analyses examined seasonal, sex and age-class variation within region. Only SEA and PWS regions were investigated due to small seasonal sample sizes in other regions (Table 1). Regional analyses included the 20 most variable dietary FAs, which each contributed more than $0.2 \%$ of the total FAs by weight in at least 1 region (Table 2). These 20 FAs accounted for $85.5 \pm 0.17 \%$ of total FAs by weight. For the within-region analyses, the largest subset of samples and FAs were used to answer specific questions (see 'Results' and Table 2). Prior to each analysis, FAs were transformed to normalize the data using a logarithmic transformation designed for compositional data (Budge et al. 2002).

\section{RESULTS}

Nine FAs (14:0, 16:0, 16:1n-7, 18:1n-9, 18:1n-7, $20: 1 n-11,20: 5 n-3,22: 5 n-3$, and 22:6n-3) accounted for between 66.6 and $84.2 \%$ of the total blubber FAs by weight for all individuals. Overall, monounsaturated FAs accounted for $55.0 \pm 0.17 \%$ whereas saturated FAs and polyunsaturated FAs accounted for $20.6 \pm 0.09$ and $24.0 \pm 0.14 \%$ of total blubber FA, respectively.

\section{Regional analysis}

FA profiles were highly variable between regions, with the isomers of 22:1 and 20:1 showing the greatest variability. Blubber FA profiles of spring pups differed significantly by region (MANOVA: $F_{60,333}=11.0, \mathrm{p}<$ 0.001 ) but there was no statistically significant sex effect $\left(F_{20,109}=1.1, \mathrm{p}=0.354\right)$ and no statistically significant region $\times$ sex interaction $\left(F_{60,333}=1.1, \mathrm{p}=0.267\right)$. Post-hoc univariate analysis indicated that 13 of the 20 FAs used differed significantly by region after applying a Bonferroni correction factor for multiple comparisons (statistically significant $p$-value $=0.003$; Fig. 3).

DFA also indicated statistically significant differences in the blubber FA profiles of SSL pups by region (Wilks' $\lambda=0.017, \chi^{2}=503.2, p<0.001$; Fig. 4). $96 \%$ (130 of 136) blubber FA profiles were correctly classified to region with a cross-validation error rate of $11.0 \%$. Misclassifications occurred in all regions: 2 AI and 2 SEA individuals were misclassified as KOD, 1 KOD individual was misclassified as PWS, and 1 PWS individual was misclassified as SEA.

\section{Seasonal, age-class and sex analysis}

\section{Southeast Alaska}

SEA pups were sampled in large numbers across all seasons (Table 1), whereas sample sizes of SEA yearlings were sufficiently large $(>20)$ only in summer and fall. Therefore, winter and spring yearlings were not included in the generalized linear model analysis. Blubber FA profiles from SEA individuals differed significantly by age-class (MANOVA: $F_{20,191}=47.9$, p < 0.001 ), season (MANOVA: $F_{60,579}=19.1, \mathrm{p}<0.001$ ) and seasonally within age-class (age-class $\times$ season interaction MANOVA: $\left.F_{20,191}=17.9, \mathrm{p}<0.001\right)$, when the same 20 FAs used in the regional analysis were included in the model (Table 2). In a DFA conducted to investigate these divergent seasonal patterns, winter and spring yearling samples were classified using the functions derived from all other samples. This analysis 
Table 2. Eumetopias jubatus. Fatty acid composition of blubber tissue from young Steller sea lions in 4 regions of their Alaskan range. Values are mean $\pm 1 \mathrm{SE}$ percent of total fatty acid by weight for all fatty acids that averaged $\geq 0.2 \%$ in any age-class/region group. Boldface indicates 20 fatty acids used in regional and SEA analyses; *: 9 variables used in PWS analysis

\begin{tabular}{|c|c|c|c|c|c|c|c|c|}
\hline \multirow{2}{*}{$\begin{array}{l}\text { Fatty acids } \\
\text { (FAs) }\end{array}$} & \multicolumn{2}{|c|}{ SEA -} & \multicolumn{2}{|c|}{$\longrightarrow$ PWS } & \multicolumn{2}{|c|}{$\longrightarrow \mathrm{KOD}-$} & \multirow{2}{*}{$\begin{array}{c}\text { Pups } \\
(\mathrm{n}=51)\end{array}$} & \multirow{2}{*}{$\begin{array}{l}\text { AI } \\
\qquad \begin{array}{l}\text { Yearlings } \\
(\mathrm{n}=5)\end{array}\end{array}$} \\
\hline & $\begin{array}{c}\text { Pups } \\
(\mathrm{n}=137)\end{array}$ & $\begin{array}{l}\text { Yearlings } \\
(\mathrm{n}=96)\end{array}$ & $\begin{array}{c}\text { Pups } \\
(\mathrm{n}=89)\end{array}$ & $\begin{array}{l}\text { Yearlings } \\
(\mathrm{n}=59)\end{array}$ & $\begin{array}{c}\text { Pups } \\
(\mathrm{n}=33)\end{array}$ & $\begin{array}{l}\text { Yearlings } \\
(\mathrm{n}=7)\end{array}$ & & \\
\hline \multicolumn{9}{|l|}{ Saturated } \\
\hline $14: 0^{*}$ & $4.96 \pm 0.07$ & $5.06 \pm 0.09$ & $5.36 \pm 0.11$ & $5.19 \pm 0.12$ & $4.57 \pm 0.09$ & $4.55 \pm 0.18$ & $4.96 \pm 0.09$ & $4.33 \pm 0.23$ \\
\hline $15: 0$ & $0.36 \pm 0.01$ & $0.32 \pm 0.01$ & $0.35 \pm 0.01$ & $0.31 \pm 0.01$ & $0.32 \pm 0.01$ & $0.30 \pm 0.02$ & $0.33 \pm 0.01$ & $0.31 \pm 0.02$ \\
\hline $16: 0^{*}$ & $13.71 \pm 0.12$ & $12.22 \pm 0.13$ & $12.55 \pm 0.13$ & $10.65 \pm 0.14$ & $12.24 \pm 0.21$ & $12.10 \pm 0.64$ & $11.35 \pm 0.23$ & $10.93 \pm 0.59$ \\
\hline 7methyl 16:0 & $0.26 \pm 0.01$ & $0.23 \pm 0.01$ & $0.24 \pm 0.01$ & $0.22 \pm 0.01$ & $0.24 \pm 0.01$ & $0.19 \pm 0.01$ & $0.25 \pm 0.01$ & $0.24 \pm 0.01$ \\
\hline $17: 0$ & $0.24 \pm 0.01$ & $0.21 \pm 0.01$ & $0.22 \pm 0.01$ & $0.23 \pm 0.01$ & $0.24 \pm 0.01$ & $0.31 \pm 0.02$ & $0.22 \pm 0.01$ & $0.22 \pm 0.02$ \\
\hline $18: 0$ & $1.89 \pm 0.03$ & $1.82 \pm 0.05$ & $1.67 \pm 0.04$ & $1.80 \pm 0.08$ & $1.52 \pm 0.05$ & $2.13 \pm 0.11$ & $1.43 \pm 0.05$ & $1.44 \pm 0.15$ \\
\hline \multicolumn{9}{|l|}{ Monounsaturated } \\
\hline $14: 1 \mathrm{n}-5$ & $0.38 \pm 0.01$ & $0.39 \pm 0.01$ & $0.40 \pm 0.01$ & $0.41 \pm 0.02$ & $0.42 \pm 0.02$ & $0.31 \pm 0.02$ & $0.43 \pm 0.01$ & $0.40 \pm 0.03$ \\
\hline $16: 1 n-11$ & $0.45 \pm 0.01$ & $0.43 \pm 0.01$ & $0.47 \pm 0.01$ & $0.39 \pm 0.01$ & $0.46 \pm 0.01$ & $0.37 \pm 0.04$ & $0.54 \pm 0.02$ & $0.45 \pm 0.05$ \\
\hline $16: 1 n-9$ & $0.44 \pm 0.01$ & $0.40 \pm 0.01$ & $0.38 \pm 0.01$ & $0.34 \pm 0.01$ & $0.38 \pm 0.01$ & $0.40 \pm 0.02$ & $0.37 \pm 0.01$ & $0.38 \pm 0.02$ \\
\hline $16: 1 n-7^{*}$ & $8.59 \pm 0.13$ & $8.49 \pm 0.14$ & $8.48 \pm 0.13$ & $7.67 \pm 0.24$ & $10.14 \pm 0.22$ & $7.01 \pm 0.55$ & $8.89 \pm 0.29$ & $8.65 \pm 0.52$ \\
\hline $17: 1$ & $0.44 \pm 0.01$ & $0.38 \pm 0.01$ & $0.41 \pm 0.01$ & $0.35 \pm 0.01$ & $0.45 \pm 0.03$ & $0.41 \pm 0.04$ & $0.41 \pm 0.01$ & $0.40 \pm 0.03$ \\
\hline $18: 1 n-13$ & $0.24 \pm 0.01$ & $0.20 \pm 0.01$ & $0.32 \pm 0.01$ & $0.26 \pm 0.01$ & $0.27 \pm 0.01$ & $0.24 \pm 0.02$ & $0.38 \pm 0.02$ & $0.25 \pm 0.02$ \\
\hline $18: 1 n-11$ & $2.22 \pm 0.08$ & $2.79 \pm 0.11$ & $2.84 \pm 0.10$ & $2.94 \pm 0.11$ & $2.26 \pm 0.13$ & $2.27 \pm 0.44$ & $3.74 \pm 0.24$ & $3.44 \pm 0.74$ \\
\hline 18:1n-9* & $26.41 \pm 0.24$ & $26.86 \pm 0.28$ & $24.26 \pm 0.22$ & $23.66 \pm 0.28$ & $26.10 \pm 0.34$ & $27.13 \pm 0.63$ & $22.39 \pm 0.73$ & $23.47 \pm 1.41$ \\
\hline $18: 1 n-7^{*}$ & $4.84 \pm 0.10$ & $4.91 \pm 0.10$ & $4.26 \pm 0.08$ & $4.21 \pm 0.10$ & $5.55 \pm 0.19$ & $5.06 \pm 0.19$ & $4.68 \pm 0.14$ & $5.33 \pm 0.50$ \\
\hline $18: 1 n-5$ & $0.50 \pm 0.01$ & $0.45 \pm 0.01$ & $0.54 \pm 0.01$ & $0.50 \pm 0.01$ & $0.41 \pm 0.01$ & $0.43 \pm 0.02$ & $0.48 \pm 0.01$ & $0.44 \pm 0.03$ \\
\hline 20:1n-11* & $3.95 \pm 0.08$ & $4.93 \pm 0.15$ & $6.74 \pm 0.27$ & $8.62 \pm 0.15$ & $4.39 \pm 0.28$ & $6.28 \pm 0.85$ & $7.59 \pm 0.59$ & $6.59 \pm 1.65$ \\
\hline 20:1n-9 & $3.02 \pm 0.08$ & $3.72 \pm 0.10$ & $2.64 \pm 0.06$ & $3.10 \pm 0.10$ & $2.54 \pm 0.15$ & $3.27 \pm 0.27$ & $3.16 \pm 0.11$ & $3.42 \pm 0.52$ \\
\hline $20: 1 \mathrm{n}-7$ & $0.35 \pm 0.01$ & $0.34 \pm 0.01$ & $0.31 \pm 0.01$ & $0.35 \pm 0.01$ & $0.33 \pm 0.07$ & $0.44 \pm 0.02$ & $0.36 \pm 0.02$ & $0.37 \pm 0.02$ \\
\hline $22: 1 n-11^{*}$ & $1.36 \pm 0.06$ & $1.61 \pm 0.08$ & $2.03 \pm 0.10$ & $2.88 \pm 0.08$ & $1.16 \pm 0.10$ & $1.67 \pm 0.29$ & $2.39 \pm 0.20$ & $1.95 \pm 0.54$ \\
\hline $22: 1 n-9$ & $0.28 \pm 0.01$ & $0.33 \pm 0.01$ & $0.29 \pm 0.01$ & $0.38 \pm 0.01$ & $0.24 \pm 0.01$ & $0.43 \pm 0.04$ & $0.40 \pm 0.02$ & $0.35 \pm 0.07$ \\
\hline \multicolumn{9}{|l|}{ Polyunsaturated } \\
\hline $16: 2 n-4$ & $0.20 \pm 0.01$ & $0.21 \pm 0.01$ & $0.21 \pm 0.01$ & $0.22 \pm 0.01$ & $0.20 \pm 0.01$ & $0.27 \pm 0.02$ & $0.22 \pm 0.01$ & $0.29 \pm 0.02$ \\
\hline $16: 3 n-6$ & $0.38 \pm 0.01$ & $0.41 \pm 0.01$ & $0.33 \pm 0.01$ & $0.30 \pm 0.01$ & $0.43 \pm 0.02$ & $0.28 \pm 0.03$ & $0.42 \pm 0.02$ & $0.38 \pm 0.03$ \\
\hline $18: 2 n-6$ & $1.45 \pm 0.03$ & $1.32 \pm 0.02$ & $1.47 \pm 0.02$ & $1.41 \pm 0.02$ & $1.32 \pm 0.04$ & $1.51 \pm 0.10$ & $1.51 \pm 0.02$ & $1.45 \pm 0.06$ \\
\hline $18: 3 n-4$ & $0.22 \pm 0.01$ & $0.27 \pm 0.01$ & $0.17 \pm 0.01$ & $0.18 \pm 0.01$ & $0.07 \pm 0.01$ & $0.06 \pm 0.01$ & $0.10 \pm 0.01$ & $0.08 \pm 0.01$ \\
\hline $18: 3 n-3$ & $0.62 \pm 0.02$ & $0.49 \pm 0.01$ & $0.65 \pm 0.01$ & $0.58 \pm 0.01$ & $0.54 \pm 0.02$ & $0.58 \pm 0.05$ & $0.58 \pm 0.02$ & $0.55 \pm 0.04$ \\
\hline $18: 4 n-3$ & $0.68 \pm 0.02$ & $0.50 \pm 0.01$ & $0.68 \pm 0.02$ & $0.58 \pm 0.02$ & $0.61 \pm 0.03$ & $0.65 \pm 0.08$ & $0.79 \pm 0.03$ & $0.66 \pm 0.11$ \\
\hline 18:4n-1 & $0.31 \pm 0.01$ & $0.29 \pm 0.01$ & $0.26 \pm 0.01$ & $0.21 \pm 0.01$ & $0.35 \pm 0.02$ & $0.20 \pm 0.02$ & $0.38 \pm 0.02$ & $0.29 \pm 0.05$ \\
\hline $20: 2 n-6$ & $0.31 \pm 0.01$ & $0.24 \pm 0.01$ & $0.30 \pm 0.01$ & $0.29 \pm 0.01$ & $0.25 \pm 0.01$ & $0.18 \pm 0.06$ & $0.30 \pm 0.01$ & $0.26 \pm 0.01$ \\
\hline $20: 3 n-6$ & $0.12 \pm 0.01$ & $0.13 \pm 0.01$ & $0.13 \pm 0.01$ & $0.13 \pm 0.01$ & $0.12 \pm 0.01$ & $0.25 \pm 0.04$ & $0.12 \pm 0.01$ & $0.12 \pm 0.01$ \\
\hline $20: 4 n-6$ & $0.69 \pm 0.03$ & $0.63 \pm 0.01$ & $0.63 \pm 0.01$ & $0.55 \pm 0.01$ & $0.68 \pm 0.02$ & $0.33 \pm 0.11$ & $0.59 \pm 0.01$ & $0.63 \pm 0.05$ \\
\hline $20: 3 n-3$ & $0.11 \pm 0.01$ & $0.10 \pm 0.01$ & $0.15 \pm 0.01$ & $0.13 \pm 0.01$ & $0.22 \pm 0.01$ & $0.38 \pm 0.10$ & $0.11 \pm 0.01$ & $0.11 \pm 0.01$ \\
\hline $20: 4 n-3$ & $1.09 \pm 0.04$ & $0.89 \pm 0.02$ & $1.07 \pm 0.02$ & $1.01 \pm 0.02$ & $0.95 \pm 0.04$ & $1.02 \pm 0.11$ & $1.05 \pm 0.03$ & $0.98 \pm 0.04$ \\
\hline $20: 5 n-3^{*}$ & $4.61 \pm 0.08$ & $4.13 \pm 0.08$ & $4.14 \pm 0.10$ & $3.82 \pm 0.13$ & $5.90 \pm 0.34$ & $3.63 \pm 0.40$ & $4.85 \pm 0.17$ & $4.91 \pm 0.64$ \\
\hline $21: 5 n-3$ & $0.34 \pm 0.01$ & $0.35 \pm 0.01$ & $0.32 \pm 0.01$ & $0.31 \pm 0.01$ & $0.41 \pm 0.01$ & $0.37 \pm 0.03$ & $0.42 \pm 0.01$ & $0.43 \pm 0.04$ \\
\hline $22: 5 n-3$ & $3.48 \pm 0.05$ & $3.88 \pm 0.07$ & $3.66 \pm 0.07$ & $4.29 \pm 0.11$ & $3.80 \pm 0.09$ & $4.22 \pm 0.13$ & $3.62 \pm 0.09$ & $4.36 \pm 0.28$ \\
\hline $22: 6 n-3^{*}$ & $8.13 \pm 0.03$ & $7.78 \pm 0.11$ & $8.97 \pm 0.20$ & $9.48 \pm 0.26$ & $7.80 \pm 0.22$ & $8.52 \pm 0.32$ & $7.69 \pm 0.17$ & $8.68 \pm 0.85$ \\
\hline \multicolumn{9}{|l|}{$\%$ total FA } \\
\hline Saturated & $22.1 \pm 0.15$ & $20.5 \pm 0.19$ & $21.0 \pm 0.17$ & $19.0 \pm 0.21$ & $19.7 \pm 0.24$ & $20.1 \pm 0.77$ & $19.2 \pm 0.24$ & $18.1 \pm 0.50$ \\
\hline Monounsaturated & $53.8 \pm 0.31$ & $56.6 \pm 0.24$ & $54.7 \pm 0.46$ & $56.4 \pm 0.51$ & $55.5 \pm 0.52$ & $56.1 \pm 1.10$ & $56.5 \pm 0.49$ & $56.4 \pm 2.01$ \\
\hline Polyunsaturated & $24.1 \pm 0.27$ & $22.9 \pm 0.22$ & $24.3 \pm 0.42$ & $24.6 \pm 0.43$ & $24.8 \pm 0.83$ & $23.8 \pm 0.83$ & $24.2 \pm 0.33$ & $25.6 \pm 1.84$ \\
\hline
\end{tabular}

also indicated significant seasonal and age-class differences (Wilks' $\lambda=0.005, \chi^{2}=1075.6, \mathrm{p}<0.001$; Fig. 5), correctly classified $90.6 \%$ of all samples $(\mathrm{n}=$ 233) to season and $90.1 \%$ of samples to the correct age-class (Fig. 5). Misclassifications by age-class were due to winter and spring yearling samples being assigned to winter and spring pup categories, respectively. Seasonal misclassifications were the result of overlap between fall and winter samples (Fig. 5). Posthoc analysis indicated that the significant interaction between age and season resulted from differences between pups and yearlings in summer, whereas there was no statistically significant difference in the FA profiles of pups and yearlings in other seasons.

Sex and age-class differences were examined separately from seasonal differences in order to 


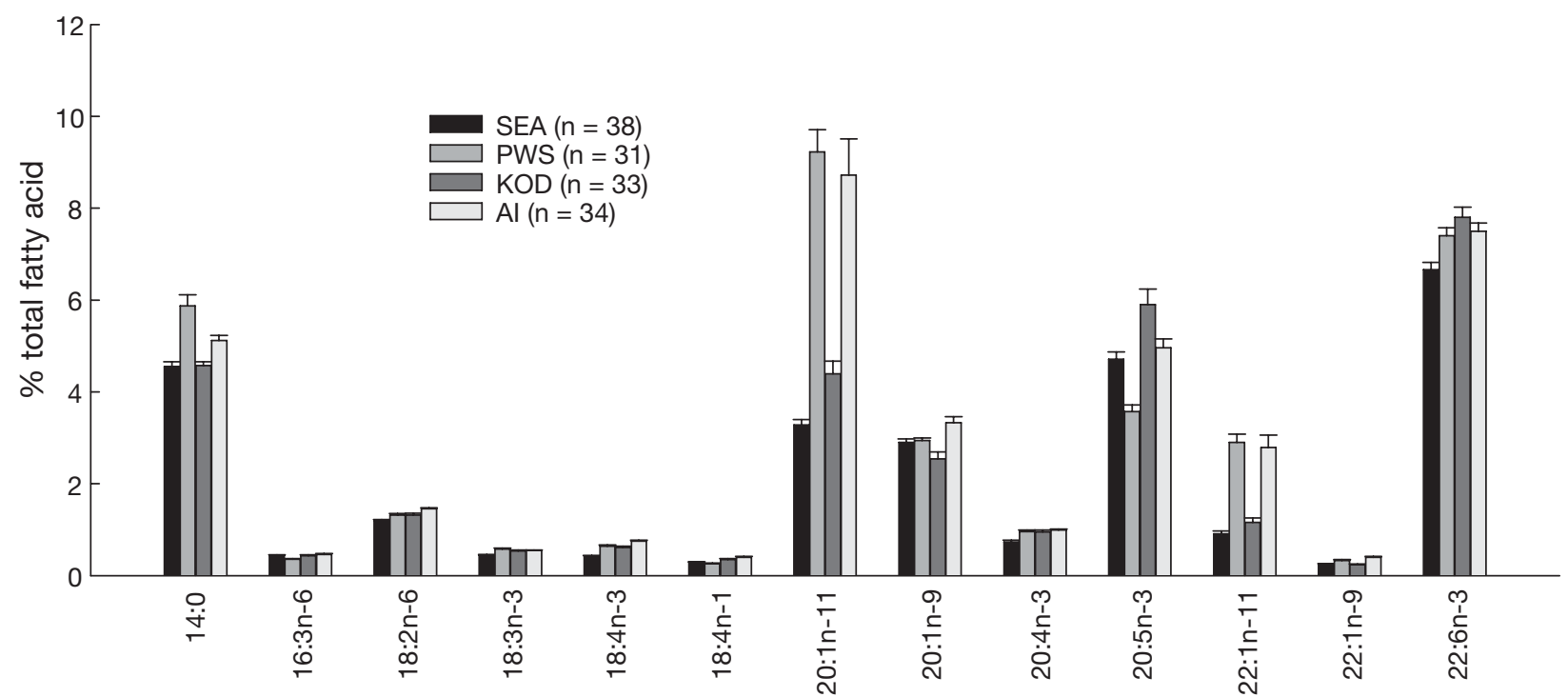

Fig. 3. Eumetopias jubatus. Percent composition by weight of the 13 fatty acids which differed significantly by region in blubber of spring pups (9 to 12 mo old). Region abbreviations as in Fig. 1 legend

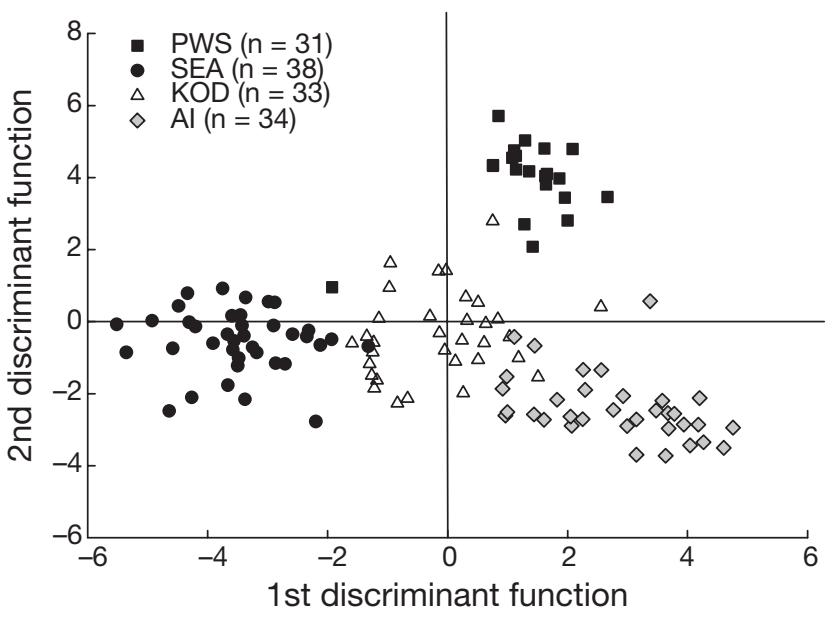

Fig. 4. Eumetopias jubatus. Discriminant functions plot of blubber fatty acid profiles from spring (March 1 to May 31) pups (9 to 12 mo old) in SE Alaska (SEA), Prince William Sound (PWS), Kodiak (KOD) and Aleutian Islands (AI). First discriminant function explained $52.9 \%$ of variation between samples and was most influenced by 20:1n-11, 18:4n-3, 20:4n-3; second discriminant function explained an additional $42.5 \%$ of variation and was most influenced by $22: 1 n-11$ and $20: 5 n-3$

maximize the number of samples available for analysis. Using the same set of variables as in the previous analysis, blubber FA profiles from SEA still differed significantly between age-classes (MANOVA: $\left.F_{20,210}=18.1, \mathrm{p}<0.001\right)$, but were similar between sexes $\left(F_{20,210}=1.4, \mathrm{p}=0.146\right)$ and between sexes within age-class (interaction term: $\left.F_{20,210}=1.4, \mathrm{p}=0.107\right)$.

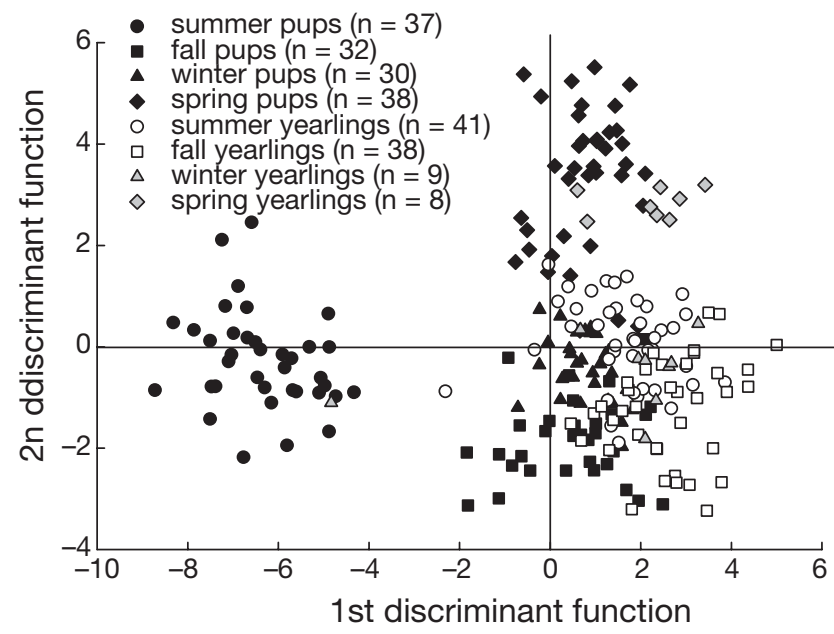

Fig. 5. Eumetopias jubatus. Discriminant function plot of blubber fatty acid profiles of young $(<24 \mathrm{mo})$ Steller sea lions by season and age-class in SE Alaska. First discriminant function explained $63.7 \%$ of variation among samples and was most influenced by 16:3n-6 and 20:1n-9; second discriminant function explained an additional $19.7 \%$ of variation and was most influenced by $18: 3 n-4,18: 1 n-7$ and $22: 1 n-11$

\section{Prince William Sound}

Due to the small number of PWS pups sampled in summer and PWS yearlings sampled in summer and spring (Table 1), only 9 FAs (Table 2 ) were included as variables in the seasonal and age-class analyses. These 9 FAs were the most variable and accounted for $79.4 \pm$ $0.12 \%$ of the total FA by weight. As in SEA, blubber FA profiles of sea lions from PWS differed significantly 
between age-class (MANOVA: $F_{9,134}=39.8, \mathrm{p}<0.001$ ) and season $\left(F_{18,270}=14.7, \mathrm{p}<0.001\right)$. The interaction between age-class and season was also statistically significant $\left(F_{18,270}=8.7, \mathrm{p}<0.001\right)$ suggesting that seasonal changes in diet differed between pups and yearlings in PWS. A DFA (conducted using the same 9 variables) also indicated statistically significant differences by season and age-class (Wilks' $\lambda=0.036, \chi^{2}=465.0$, $\mathrm{p}<0.001$; Fig. 6). This analysis correctly classified $83.8 \%$ of blubber samples $(\mathrm{n}=148)$ to season and $87.2 \%$ to age-class (Fig. 6). Most seasonal misclassifications occurred among yearlings while most age-class misclassifications involved spring samples.

Pooling data over season and including sex in the model indicated that blubber FA profiles from PWS differed significantly between age-classes (MANOVA: $\left.F_{9,136}=16.6, \mathrm{p}<0.001\right)$ and sexes $\left(F_{9,136}=3.3, \mathrm{p}=0.001\right)$. A statistically significant age $\times$ sex interaction was also evident $\left(F_{9,136}=3.3, \mathrm{p}=0.001\right)$, indicating that sex differences in blubber FA profiles were age-dependent. A DFA (Wilks' $\lambda=0.325, \chi^{2}=158.0, p<0.001$; Fig. 7) indicated that blubber FA profiles of pups were very similar between sexes, with $32.9 \%$ misclassified by sex. Among yearlings, males and females had more divergent blubber FA profiles, with only $19.1 \%$ of samples being classified to the wrong sex.

\section{DISCUSSION}

We found statistically significant differences in the blubber FA profiles, and thus diet, of young SSLs by re-

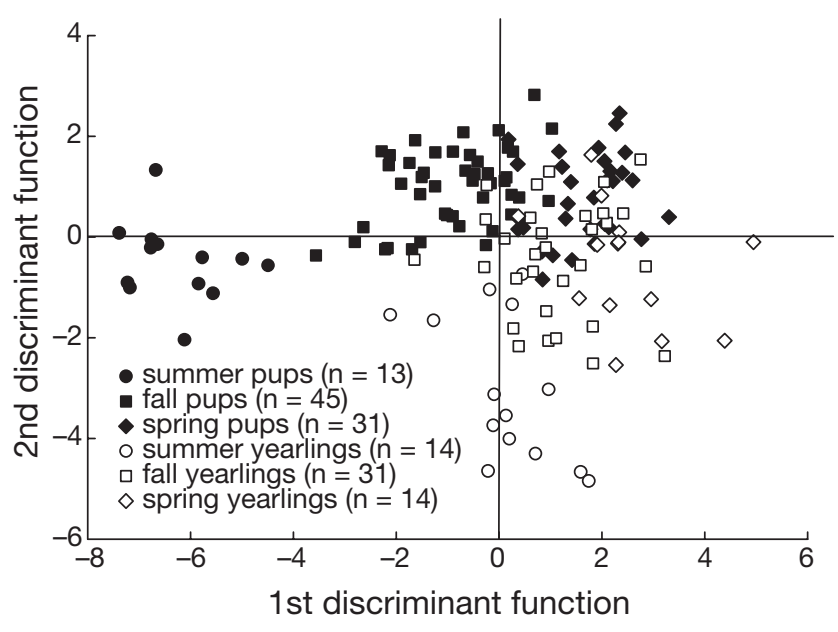

Fig. 6. Eumetopias jubatus. Discriminant function plot of blubber fatty acid profiles of young $(<24 \mathrm{mo})$ Steller sea lions by season and age-class in Prince William Sound. First discriminant function explained $71.3 \%$ of variation among samples and was most influenced by $22: 1 \mathrm{n}-11$ and $20: 1 \mathrm{n}-11$; second discriminant function explained an additional 19.4\% of variation and was most influenced by $18: 1 \mathrm{n}-7$ and 16:0

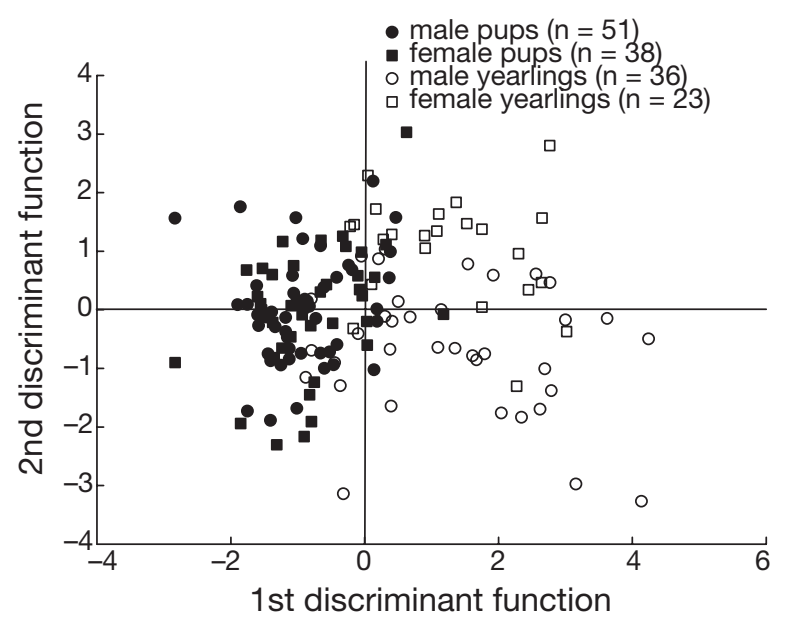

Fig. 7. Eumetopias jubatus. Discriminant function plot of blubber fatty acid profiles of young $(<24 \mathrm{mo})$ Steller sea lions by sex and age-class in Prince William Sound. First discriminant function explained $74.3 \%$ of variation and was most influenced by $22: 1 \mathrm{n}-11,20: 1 \mathrm{n}-11$ and $20: 5 \mathrm{n}-3$; second function accounted for an additional $17.9 \%$ of variation and was most influenced by $16: 1 \mathrm{n}-7,18: 1 \mathrm{n}-9$ and $22: 6 \mathrm{n}-3$

gion, season and age-class. Yearling blubber FA profiles in PWS also differed by sex. Although regional and seasonal differences in SSL diet have been known for some time (Merrick et al. 1997, Sinclair \& Zeppelin 2002), this study provides greater insight into how those factors, sex and age may influence the diet of juvenile SSL.

\section{Differences in FA profiles by region}

Only spring pups were sampled sufficiently ( $\mathrm{n}>20$ from all regions; Table 1) to investigate regional differences in FA profiles. We observed statistically significant regional variation in the blubber FA, and thus dietary intake, of spring pups (Figs. $3 \& 4$ ), which is consistent with previous studies based on analysis of stomach contents and scats from SSLs of both known (stomach contents; juveniles vs. adults) and unknown (scat) ages (Merrick \& Calkins 1996, Merrick et al. 1997, Sinclair \& Zeppelin 2002). Spring pups range in age from 9 to 12 mo and may have been nutritionally dependent, at least in part, on their mothers' milk. Assuming complete dependence, regional differences in pup blubber FA profiles would be a reflection of regional differences in the FA composition of adult female diets that were passed on to offspring through milk (Puppione et al. 1996, Iverson et al. 2001). However, recent studies of maternal attendance patterns (Trites \& Porter 2002) and the dispersal and movement patterns of young SSLs (Loughlin et al. 2003, RaumSuryan et al. 2004, Fadely et al. 2005) have suggested that some individuals may wean during the spring of 
their first year of life. If this is true, regional differences in the blubber FA profile of pups may also result from regional differences in prey consumption or in the timing of when pups begin to forage independently.

\section{Seasonal, age-class and sex variation in FA profiles}

Within regions, statistically significant seasonal and age-class differences in blubber FA profiles were evident in young SSLs from both SEA and PWS (Figs. 5 \& 6, respectively) indicating significant changes in dietary intake across temporal scales. FA blubber profiles collected from pups during the summer in SEA were particularly distinct from other season/age-class groups within SEA and differed primarily in the relative levels of 20:1n-9 and 16:3n-6 (Fig. 5). SSL pups are $<3$ mo old in the summer and are completely dependent on maternal milk due to their limited swimming and diving capability. As a result, females with young pups are limited to foraging areas near the parturition rookery. As pups grow and swimming skills mature, mother-pup pairs begin to disperse from the rookeries to winter haul-outs in the fall, where females remain until the following breeding season (Calkins \& Pitcher 1982, Raum-Suryan et al. 2004). In SEA, many haulouts are located within the calmer inside waters compared to the rookeries, located on the outer coast (Fig. 1). Analysis of scat samples indicated statistically significant differences in diet composition between individuals at rookeries and haul-outs in SEA (Trites et al. in press). As the sea lions moved to inside waters, the proportions of gadids (particularly walleye pollock), forage fish (e.g. sand lance and herring) and cephalopods increased while salmon and rockfish proportions decreased. Currently there are no data available on the FA composition of SSL prey in SEA, however the FA composition of 26 prey species in PWS has been examined (Iverson et al. 2002) and indicates that the relative amount of 20:1n-9 is higher in walleye pollock, herring, and cephalopods than in salmon species or rockfish. A similar trend in 16:3n-6 is also present among these prey types sampled from PWS. Assuming similar trends in the FA composition of prey in SEA, the distinct change in blubber FA profiles between summer and fall pups would appear to reflect this change in the diet of adult females, who passed this change on to their pups through milk production (Puppione et al. 1996, Iverson et al. 2001). However, it should be noted that this assumption is somewhat limited, since several studies (Budge et al. 2002, Iverson et al. 2002) have shown regional and geographical differences in prey FA composition.

Blubber FA profiles of SSL pups in SEA also varied between the fall, winter and spring (Fig. 5), such that movement of pairs to haul-outs could not account for all seasonal variation. Seasonal changes in the diet of SSL have previously been described from scat (Merrick et al. 1997, Sinclair \& Zeppelin 2002) and stomach content (Merrick \& Calkins 1996) analysis. Sinclair \& Zeppelin (2002) showed that the seasonal frequency of major prey species in the scats of SSL from the western stock paralleled seasonal patterns in the nearshore spawning and migratory movements of these prey, suggesting that SSL target dense prey aggregations which result from annual life cycle events of the prey. If similar foraging behavior strategies are employed among individuals in the eastern population, the seasonal changes evident in the blubber FA profiles of SEA pups are likely to represent seasonal shifts in mothers' diets, and thus the FA composition of their milk, as they forage on seasonally aggregated prey. Due to the lack of detailed data on the FA composition of prey in the SEA region, it is unclear from the predator data which prey species are responsible for generating these differences.

Seasonal changes in the blubber FA profiles of yearling SSLs from SEA were also evident and, with the exception of the summer season, mirrored the seasonal trends of pup blubber FA profiles in this region. If SEA yearlings were nutritionally independent at the time of sampling this would reflect seasonal changes in prey selected by foraging yearlings. However, it is also possible that some of these individuals were not yet weaned and these seasonal changes in FA profiles of the blubber reflect seasonal prey preferences of lactating females similar to that seen in pups from this area. There is behavioral evidence that a high proportion $(\sim 80 \%)$ of SSL in SEA continue to be nursed through their second year (Pitcher et al. 2004).

In PWS, young SSLs also showed statistically significant seasonal and age-class differences in their blubber FA profile (Fig. 6), with summer pups again being the most distinct from all other groups. The FA profile of summer and fall pups contained a lower proportion of 22:1n-11 and 20:1n-11 relative to spring pups and all yearling samples. These 2 dietary FAs tend to be quite high in some marine fishes (e.g. up to 9-12 and 7-10\% respectively in herring, cephalopods, and walleye pollock; Iverson et al. 2002) compared to milk samples collected via gastric intubation of young SSLs from this region $(22: 1 \mathrm{n}-11=1.0$ to $3.0 \%, 20: 1 \mathrm{n}-11=2$ to $5 \%$; Alaska Department of Fish \& Game unpubl. data). Thus, spring PWS pups with relatively higher levels of 20:1n-11 and 22:1n-11 could either be directly ingesting some marine prey high in these FAs, or the diets of mothers could have shifted from fall to spring. However, as stated previously, we do not yet know what proportion of spring pup or yearling diet is derived from maternal support. Similar to SEA, seasonal varia- 
tion in blubber FA profiles was also significant among PWS yearlings; however, yearlings' seasonal patterns did not mirror the seasonal changes of PWS pup blubber. These seasonal differences among PWS yearlings probably represent changes in the prey species seasonally available (Merrick \& Calkins 1996, Sinclair \& Zeppelin 2002) to these young foragers.

Significant sex differences were found in the blubber FA profiles of PWS yearlings, but not among the profiles of SEA yearlings. In this size-dimorphic species, males are significantly larger than females at 2 to 4 wk of median age (Merrick et al. 1995), with differences in growth rate continuing through maturity (Winship et al. 2001). In many marine mammal species, body size is directly correlated with diving and hence foraging ability due to the relationships between body size, oxygen storage capacity and mass-specific metabolic rate (Castellini \& Kooyman 1989). Sex differences in the diving behavior and movement pattern of young SSLs have been documented (Raum-Suryan et al. 2004, Rehberg 2005) and are consistent with sex differences in other sizedimorphic marine mammal species (Le Boeuf et al. 2000). Juvenile (>12 mo) male SSLs make significantly longer and deeper dives than females (Rehberg 2005). In contrast, time-at-sea, trip distance and trip duration are significantly greater among female SSL juveniles (Raum-Suryan et al. 2004). Thus, the larger size of male SSL yearlings compared to females appears to result in differences in the way each sex utilizes its habitat and resources. These sex differences in diving characteristics may allow independently foraging males and females in PWS access to different prey resources which are reflected in their blubber FA profiles. Although this would explain the sex differences in blubber FA profiles of PWS yearlings, it is not known whether they were independently foraging or still suckling. The lack of sex differences in SEA yearlings could result from either continued suckling, or from male and female yearlings foraging similarly in the environment.

Until it is possible to identify the source of dietary FA (maternal attendance or independent foraging), the questions regarding when individuals transition to independent foraging and what prey species are important to juvenile SSLs remain. Quantitative estimation of diet composition for individual juvenile SSLs using the method of quantitative fatty acid signature analysis (Iverson et al. 2004) will be the next important step. With appropriate sampling of prey species, together with SSL milk, from all regions and an understanding of how young sea lions metabolize the meals they ingest, a quantitative estimate of diet composition and, in turn, a better understanding of the variability in weaning time can be gained.
Acknowledgements. We thank the SSL capture teams at the Alaska Department of Fish \& Game (ADF\&G) and the National Marine Mammal Laboratory (NMML), Seattle, for their dedication and assistance in obtaining blubber samples from young SSLs for this project. We also thank B. Applegate, E. Dodds, R. Douglas, A. Geldenhuys, M. McCoy and D. Musie for their laboratory assistance. This research was funded by a North Pacific Marine Research Institute grant to L.D.R. and J.M.K. (T-2120) and through a cooperative agreement with NOAA and ADF\&G (No. NA17FX1079). Research was conducted under US Marine Mammal Protection Act and Endangered Species Act Permit Nos. 358-1564 (to ADF\&G) and 782-1532 (to NMML), ADF\&G Animal Care and Use Committee Permit 03-002, University of Alaska Anchorage Animal Care \& Use Committee Permit 2003Beck1 and, within the Alaska National Maritime Refuge, by US Fish and Wildlife Service special permit. We thank W. D. Bowen, C. A. Clark, T. Haase, K. Hastings and 4 anonymous reviewers for their comments on earlier drafts of the manuscript.

\section{LITERATURE CITED}

Ackman RG (1980) Fish lipids, Part 1. In: Connell JJ (ed) Advances in fish science and technology. Fishing News Books, Surrey, p 86-103

Ackman RG, Eaton CA (1966) Lipid of the fin whale (Balaenoptera physalus) from North Atlantic waters. III. Occurrence of eicosenoic and docosenoic fatty acids in the zooplankton Meganyctiphanes norvegica (M. Sars) and their effect on whale oil composition. Can J Biochem 44: 1561-1566

Beauplet G, Barbraud C, Chambellant M, Guinet C (2005) Interannual variation in the post-weaning and juvenile survival of subantarctic fur seals: influence of pup sex, growth rate and oceanographic conditions. J Anim Ecol 74:1160-1172

Beck CA, Iverson SJ, Bowen WD (2005) Blubber fatty acids of grey seals reveal sex differences in the diet of a size dimorphic marine carnivore. Can J Zool 83:377-388

Bickham JW, Patton JC, Loughlin (1996) High variability for control-region sequences in a marine mammal: implications for conservation and biogeography of Steller sea lions (Eumetopias jubatus). J Mammal 77:95-108

Blumstein DT, Foggin JM (1997) Effects of vegetative variation on weaning success, overwinter survival and social group density in golden marmots (Marmota caudate aurea). J Zool 243:57-69

Bowen WD (2000) Reconstruction of pinniped diets: accounting for complete digestion of otoliths and cephalopod beaks. Can J Fish Aquat Sci 57:898-905

Brandon EAA, Calkins DG, Loughlin TR, Davis RW (2005) Neonatal growth of Steller sea lion (Eumetopias jubatus) pups in Alaska. Fish Bull US 103:246-257

Budge SM, Iverson SJ, Bowen WD, Ackman RG (2002) Among- and within-species variability in fatty acid signatures of marine fish and invertebrates on the Scotian Shelf, Georges Bank, and southern Gulf of St. Lawrence. Can J Fish Aquat Sci 59:886-898

Calkins DG, Pitcher KW (1982) Population assessment, ecology and trophic relationships of Steller sea lions in the Gulf of Alaska. In: Environmental assessment of the Alaskan continental shelf. Final reports of Principal Investigators No. 19. US Department of Commerce and US Department of Interior, Boulder, CO p 447-547

Calkins DG, McAllister DC, Pitcher KW, Pendleton GW (1999) Steller sea lion status and trend in SE Alaska: 
1979-1997. Mar Mamm Sci 15:462-477

Castellini MA, Kooyman GL (1989) Behavior of freely diving animals. Undersea Biomed Res 16:355-362

Cook HW (1991) Fatty acid desaturation and chain elongation in eucaryotes. In: Vance DE, Vance JE (eds) Biochemistry of lipids and membranes. Elsevier Science, Amsterdam, p 141-169

Cooper MH (2004) Fatty acid metabolism in marine carnivores: implications for quantitative estimation of predator diets. PhD thesis, Dalhousie University, Halifax

Craig MP, Ragen TJ (1999) Body size, survival, and decline of juvenile Hawaiian monk seals, Monachus schauinslandi. Mar Mamm Sci 15:786-809

Dodds ED, McCoy MR, Geldenhuys A, Rea LD, Kennish JM (2004) Microscale recovery of total lipids from fish tissue by accelerated solvent extraction. J Am Oil Chem Soc 81: 835-840

Fadely BS, Robson BW, Sterling JT, Greig AG, Call KA (2005) Immature Steller sea lion (Eumetopias jubatus) dive activity in relation to habitat features of the eastern Aleutian Islands. Fish Oceanogr 14(Suppl 1):243-258

Folch J, Lees M, Stanley GH (1957) A simple method for the isolation and purification of total lipids from animal tissues. J Biol Chem 226:497-509

Grahl-Nielsen $\mathrm{O}$, Andersen $\mathrm{M}$, Derocher AE, Lydersen $\mathrm{C}$, Wigg O, Kovacs KM (2003) Fatty acid composition of the adipose tissue of polar bears and of their prey: ringed seals, bearded seals and harp seals. Mar Ecol Prog Ser 265:275-282

Grahl-Nielsen $O$, Andersen M, Derocher AE, Lydersen C, Wigg O, Kovacs KM (2004) Reply comment to GrahlNielsen et al. (2003): sampling, data treatment and prediction in investigations on fatty acids in marine mammals. Mar Ecol Prog Ser 281:303-306

Heath RB, Delong R, Jameson V, Bradley D, Spraker T (1997) Isoflurane anesthesia in free ranging sea lion pups. J Wildl Dis 33:206-210

Herman DP, Burrows DG, Wade PR, Durban JW, Matkin CO, LeDuc RG, Barrett-Lenard LG, Krahn MM (2005) Feeding ecology of eastern North pacific whales Orcinus orca from fatty acid, stable isotope, and organochlorine analyses of blubber biopsies. Mar Ecol Prog Ser 302:275-291

Holland DL, Davenport J, East J (1990) The fatty acid composition of the leatherback turtle Demochelys coriacea and its jellyfish prey. J Mar Biol Assoc UK 70:761-770

Hoover-Miller AA (1988) Harbor seal, Phoca vitulina. In: Lentfer JW (ed) Selected marine mammals of Alaska: species accounts with research and management recommendations. Marine Mammal Commission, Washington, DC, $\mathrm{p}$ 125-158

Iverson SJ, Frost KJ, Lowry LF (1997) Fatty acid signatures reveal fine scale structure of foraging distribution of harbor seals and their prey in Prince William Sound, Alaska. Mar Ecol Prog Ser 151:255-271

Iverson SJ, McDonald JE, Smith, LK (2001) Changes in the diet of free-ranging black bears in years of contrasting food availability revealed through milk fatty acids. Can J Zool 79:2268-2279

Iverson SJ, Frost KJ, Lang SLC (2002) Fat content and fatty acid composition of forage fish and invertebrates in Prince William Sound, Alaska: factors contributing to among and within species variability. Mar Ecol Prog Ser 241:161-181

Iverson SJ, Field C, Bowen WD, Blannchard W (2004) Quantitative fatty acid signature analysis: a new method of estimating predator diets. Ecol Monogr 74:211-235

Jobling M, Breiby A (1986) The use and abuse of fish otoliths in studies of feeding habits of marine piscivores. Sarsia 71 :
$265-274$

King JC, Gelatt TS, Pitcher KW Pendleton GW (2007) A fieldbased method for estimating age in free-ranging steller sea lions (Eumetopias jubatus) less than twenty four months of age. Mar Mamm Sci 23(2):262-271

Koopman HN (2001) The structure and function of the blubber of odontocetes. PhD dissertation, Duke University, Durham, NC

Le Boeuf BJ, Crocker DE, Costa DP, Blackwell SB, Webb PM, Houser DS (2000) Foraging ecology of northern elephant seals. Ecol Monogr 70:353-382

Lhuillery C, Mebarki S, Lecourtier MJ, Demarne Y (1988) Influence of different dietary fats on the incorporation of exogenous fatty acids into rat adipose glycerides. J Nutr 118:1447-1454

Loughlin TR, Sterling JT, Merrick RL, Sease JL, York AE (2003) Diving behavior of immature Steller sea lions (Eumetopias jubatus). Fish Bull US 101:566-582

Marchetti K, Price T (1989) Differences in the foraging of juvenile and adult birds: the importance of developmental constraints. Biol Rev 64:51-70

Merrick RL, Calkins DG (1996) Importance of juvenile walleye pollock, Theragra chalcogramma, in the diet of Gulf of Alaska Steller sea lions, Eumetopias jubatus. NOAA Tech Rep NMFS 126:153-166

Merrick RL, Loughlin TR (1997) Foraging behavior of adult female and young-of-the-year Steller sea lions in Alaskan waters. Can J Zool 75:776-786

Merrick RL, Loughlin TR, Calkins DG (1987) Decline in abundance of the northern sea lion, Eumetopias jubatus, in Alaska, 1956-86. Fish Bull (Wash DC) 85:351-365

Merrick RL, Brown R, Calkins DG, Loughlin TR (1995) A comparison of Steller sea lion, Eumetopias jubatus, pup masses between rookeries with increasing and decreasing populations. Fish Bull (Wash DC) 93:753-758

Merrick RL, Chumbley MK, Byrd GV (1997) Diet diversity of Steller sea lions (Eumetopias jubatus) and their population decline in Alaska: a potential relationship. Can J Fish Aquat Sci 54:1342-1348

Pendleton GW, Pitcher KW, Fritz LW, York AE and 5 others (2006) Survival of Steller sea lions in Alaska: a comparison of increasing and decreasing populations. Can J Zool 84: 1163-1172

Pierce GJ, Boyle PR (1991) A review of methods for diet analysis in piscivorous marine mammals. Oceanogr Mar Biol Annu Rev 29:409-486

Pitcher KW, Calkins DG (1981) Reproductive biology of Steller sea lions in the Gulf of Alaska. J Mammal 62: 599-605

Pitcher KW, Pendleton GW, Gelatt TS (2004) Estimation of weaning status of juvenile Steller sea lions using markresight models. Abstracts: 22nd Wakefield Fisheries Symposium: sea lions of the world, Anchorage. Alaska SeaGrant College Program. Fairbanks, AK, p 101

Puppione DL, Kuehlthau CM, Jandack RJ, Costa DP (1996) Chylomicron triacylglycerol fatty acids in suckling northern elephant seals (Mirounga angustirostris) resemble the composition and distribution of fatty acids in milk fat. Comp Biochem Physiol B 114:53-57

Raclot T, Groscolas R, Cherel Y (1998) Fatty acids evidence for the importance of myctophid fishes in the diet of king penguins, Aptenodytes patagonicus. Mar Biol 132:523-533

Raum-Suryan KL, Rehberg MJ, Pendleton GW, Picher KW, Gelatt TS (2004) Development of dispersal, movement patterns, and haul-out use by pup and juvenile Steller sea lions (Eumetopias jubatus) in Alaska. Mar Mamm Sci 20: $823-850$ 
Rehberg MJ (2005) Pattern matters: changes in the organization of swimming and diving behavior by Steller sea lion juveniles in Alaska. MSc thesis, University of Alaska Anchorage

Rolseth SL, Koehler CE, Barclay RMR (1994) Differences in the diets of juvenile and adult hoary bats, Lasiurus cinereus. J Mammal 75:394-398

Sease JL, Taylor WP, Loughlin TR, Pitcher KW (2001) Aerial and land-based surveys of Steller sea lions (Eumetopias jubatus) in Alaska, June, and July 1999 and 2000. NOAA Tech Memo NMFS AFSC 122:52

Sinclair EH, Zeppelin TK (2002) Seasonal and spatial differences in diet in the western stock of Steller sea lions (Eumetopius jubatus). J Mammal 83:973-990

Stevens J (1986) Applied multivariate statistics for the social sciences. Lawrence Erlbaum Associates, Mahwah, NJ

Summers LKM, Barnes SC, Fielding BA, Beysen C, Ilic V, Humphreys SM, Frayn KN (2000) Uptake of individual fatty acids into adipose tissue in relation to their presence in the diet. Am J Clin Nutr 71:1470-1477

Thiemann GW, Budge SM, Bowen WD, Iverson SJ (2004) Comment on Grahl-Nielsen et al. (2003) Fatty acid composition of the adipose tissue of polar bears and of their prey:

Editorial responsibility: Otto Kinne (Editor-in-Chief), Oldendorf/Luhe, Germany ringed seals, bearded seals and harp seals. Mar Ecol Prog Ser 281:297-301

Trites AW, Donnelly CP (2003) The decline of Steller sea lions Eumetopias jubatus in Alaska: a review of the nutritional stress hypothesis. Mammal Rev 33:3-28

Trites AW, Porter BT (2002) Attendance patterns of Steller sea lions (Eumetopias jubatus) and their young during winter. J Zool 256:547-556

Trites AW, Calkins DG, Winship AJ (in press) Diets of Steller sea lions (Eumetopias jubatus) in SE Alaska from 1993-1999. Fish Bull (Wash DC)

Walton MJ, Henderson RJ, Pomeroy PP (2000) Using blubber fatty acid profiles to distinguish dietary differences between grey seals Halichoerus grypus from two UK breeding colonies. Mar Ecol Prog Ser 193:201-208

Winship AJ, Trites AW, Calkins DG (2001) Growth in body size of the Steller sea lion (Eumetopias jubatus). J Mammal 82:500-519

York AE (1994) The population dynamics of northern sea lions, 1975-1985. Mar Mamm Sci 10:38-51

Zenteno-Savin T, Castellini MA, Rea LD, Fadely BS (1997) Plasma haptoglobin levels in threatened Alaskan pinniped populations. J Wildl Dis 33:64-71

Submitted: December 6, 2005; Accepted: October 6, 2006 Proofs received from author(s): April 26, 2007 